\title{
The Prosperity Gospel, the decolonisation of Theology, and the abduction of missionary imagination
}

\section{CJP (Nelus) Niemandt ${ }^{1}$}

\section{Abstract}

This research focussed on one of the most important social movements and contextual challenges in the African context - the explosive growth of the 'prosperity gospel' in Africa. It investigated this phenomenon from a missiological and African perspective, but in close relation to the discourses on decoloniality and decolonialisation, and asked if the prosperity gospel is a new form of colonialization. The research attended to the historical roots and theology of the prosperity gospel. It identified the core issue as one of contextualisation and investigated the prosperity gospel from a 'glocal' perspective. This brought the relationship between the prosperity gospel and globalisation (global) as well as local economic realities into the equation. Conclusions were made regarding the complex question whether the prosperity gospel can be regarded as a form of colonialization. The research found that the underlying epistemology is more oriented towards buttressing the worldview of global capitalism than deconstructing the political, social, and cultural domination established by Europeans and their Euro-North American descendants. It also concluded that the prosperity gospel is a spiritualisation of materiality and celebration of classic symbols of surplus/excess and consumerism. However, when attention was paid to local narratives and theologies, it became apparent that some prosperity churches have a strong focus on local communities and marginalised people and that leaders assisted in liberating empowering of members. The research concluded that this phenomenon might just lead to a particular form of African Pentecostalism that will, by itself, deconstruct coloniality and add exciting dimensions to the debate.

Key words: Prosperity gospel; Decoloniality; decolonialisation; spiritualisation of materiality.

\section{Introduction}

This research acknowledges the growing corpus of research on 'decoloniality' and the 'decolonial turn'. The legacy of the 16th century European colonisation of Africa and the continuation of colonialization by means of neoliberal economic globalisation (see the Accra-confession, World Communion of Reformed Churches, 2004.)

1 Prof Nelus Niemandt is the Head of the Department of Science of Religion and Missiology, Faculty of Theology at the University of Pretoria. He can be contacted at nelus.niemandt@up.ac.za 
are still shaping Africa. The persistence of coloniality as a power of entanglement by multiple global hierarchies of sexual, political, epistemic, economic, spiritual, linguistic, and racial forms of domination continues to influence life and ideas in Africa. The relationship between mission and Missiology on the one hand, and colonialization and coloniality on the other, is still keeping many theologians occupied in crucial theological discourses, as is evident in the theme of the South African Missiological Society 2017 congress.

This research is focussed on the methodological response of Missiology to current social movements and contextual challenges in a local, regional, and especially African context. The argument is that attention must be focused on a new form of colonialization that is sweeping through much of the 'southern' hemisphere, and especially sub-Saharan Africa, in the form of the growing influence of the so-called 'prosperity gospel'. Does the prosperity gospel represent a particular expression of coloniality? Is it yet another form of economic and spiritual domination, under the guise of spiritualised economic liberation? In the South African context, particular expressions of the prosperity gospel became the centre of public attention with an official investigation into certain practices of Christian churches by the Commission for the Promotion and Protection of the Rights of Cultural, Religious and Linguistic Communities (CRL Rights Commission). This investigation was announced on the 20 August 2015, and described as an investigative study into the commercialisation of religion (Commission for the Promotion and Protection of the Rights of Cultural, Religious and Linguistic Communities $=$ CRL Rights Commission 2015). The CRL Rights Commission chairperson, Thoko Mkhwanazi-Xalavu, described the investigation as follows:

We are launching an investigative study on the commercialisation of religion and the abuse of people's belief systems in terms of when these institutions are being run, how are they being run, where is their funding going into, who collects how much and what do they do with the money, where does the money eventually go to, what are the governing principles that are there (CRL Rights Commission 2015).

The prosperity gospel represents a rather controversial strand of global Christianity, and it cannot be labelled or bound up in a single definition. It is 'transformative in nature, adapting to contexts, and travelling through history...' (Heuser 2015:16). Heuser (2015:16, 2016:3) says its texture covers a sense of spiritual advancement but, in most cases, the emphasis is on material prosperity. There seems to be considerable concern about aspects of the prosperity gospel, as is evident from the aforementioned official investigation by the CRL Rights Commission. This is also the case in ecumenical movements - the Lausanne movement warned, in their 2010 Cape Town Commitment, that the prosperity gospel raises significant concerns. 
This research will investigate those aspects of the prosperity gospel related to the overall theme of Africanisation as a form of decolonising Missiology, and attempt to formulate a Missiological response to a very important social and theological movement by attending to the following research questions:

- What is the 'prosperity gospel' from an African perspective?

- What are the historical roots and theology of the 'prosperity gospel'?

- The relation between the prosperity gospel, mission and missionary imagination?

- What is the relationship between the prosperity gospel and globalisation?

- What is the relationship between the prosperity gospel and local (economic) realities?

- Relations between the prosperity gospel and colonialization?

It will show why a Missiological discourse on the prosperity gospel must be partand-parcel of any discussion on the Africanisation of Missiology, as a form of decolonising theology.

\section{The historical roots and theology of the Prosperity Gospel}

Hunt (2000:331) was one of the first observers to identify the impact of the prosperity gospel. He places the historical roots within the 'one-way exportation' of North American Christian-oriented movements. The prosperity gospel is placed within the Pentecostal faith (Hunt 2000:332, Heuser 2015:21), but more specifically within a USA-style religion with a tendency towards a materialist orientation. Heuser (2015:17, see Gbote \& Kgatla 2014:6) also identifies the 'American genealogy' of the prosperity gospel. He calls the post-war or Cold War Pentecostal re-invention in America the decisive historic point of reference to understanding the prosperity gospel (2016:2). Gbotoe (2013:49) shows the strong connection between American Pentecostalism and the prosperity gospel, and mentions Oral Robert as one of the important founding figures in the development of the prosperity gospel. Other influential persons include Kenneth Haggin, AA Allen, and TL Osborn (Gbotoe 2013:52). More recently, Kenneth Copeland and Creflo Dollar also played an important role. Heuser (2016:2-4, see Hunt 2000:331-332) draws attention to the impact of globalisation on the Pentecostal movement, and the resultant de-localisation from the North to the global South (due to the globalisation of Pentecostalism).

The prosperity gospel must be understood in terms of the close relationship with Pentecostalism. A brief overview by Hunt (2000:332) summarises the typical Pentecostal basics of the prosperity gospel by identifying the emphasis on the 'second baptism' (of the Spirit), the so-called 'gifts of the Spirit' (charismata such as speaking in tongues, the importance of prophecy) and the enthusiasm for revival. 
It has a fundamentalist approach and deep confidence in the truth and universal application of the Bible, and the importance of divine 'truth'.

The prosperity gospel represents a new interpretation of Pentecostal theology in the sense that it emphasises the spiritual value of earthly or material blessings. Heuser (2016:3) explains: 'The prosperity gospel undertakes grand efforts to theologise material richness, and to manifest and keep the spiritual control over money'. Certain phrases became associated with this process, such as 'naming and claiming' and 'sowing and reaping', summarising the theological ideas that religious speech and terminology can create reality and that divine blessing flows from a covenantal relationship with God (and financial contributions that show loyalty to the covenantal relationship). This makes it clear that a cause-and-effect relationship between a believer and God belongs to the core of the prosperity gospel. The 'law of faith' is a core concept in this theology - a kind of legal spiritual system that stresses the potency of faith. The typical Pentecostal confidence in faith and the tradition of faith-healing has transformed into a more material reality (and a spiritualisation of material reality). In this process, money became a prominent symbol of God's blessing. Material wealth started playing a central role in the Pentecostal imagery and understanding of communities (Heuser 2016:3). Gbotoe (2013:109) emphasises an even more problematic issue regarding the image of God - respondents in his research have redefined God as a God who wants everyone to be rich and wants humanity to be affluent and enjoy the good of all things in the world.

With the Pentecostal roots firmly established it must, however, be noted that the prosperity gospel transformed into more than a mere expression of Pentecostalism, and that it indeed moved across theological and denominational lines to form a new identity that includes facets of Pentecostalism, Holiness Evangelicalism, American Methodism, African-American Baptism and/or Dutch Reformed Calvinism (Heuser 2016:2).

\section{The Prosperity Gospel from an African perspective}

The prosperity gospel recently came into the spotlight in Africa (see Wepener and Swart 2017), due to the phenomenal growth in this particular expression of Christianity in Africa (and many other places), and due to the official attention to strands (and particular expressions) of this form of faith in South Africa by the CRL Rights Commission (CRL Rights Commission 2015).

The African context can be better understood when one understands the close relationship between the prosperity gospel and African Pentecostalism. Gbote and Kgatla (2014:3) call prosperity gospel another form of Pentecostalism. Africa quickly embraced Pentecostalism, and soon afterwards the prosperity gospel that entered Africa in the wake of Pentecostalism. A survey by the PEW Research Centre 
found that in sub-Saharan Africa, 'in most countries, more than half of Christians believe in the prosperity gospel - that God will grant wealth and good health to people who have enough faith' (PEW Research Centre 2010). Gbotoe (2013:106) mentions a figure as high as $62 \%$ in his research. Heuser (2015:23) states that the prosperity gospel demands academic reflection because it has become a tradition of thought within the full range of Christianity, and because it influences 'the multiform relief of religions in Africa'.

Post-colonial times, with its emphasis on economic transformation, material independence, and self-actualisation, proved to be a fertile context to reshape African religious landscapes (Heuser 2015:18). The economic and political situation in many African countries represented an opportunity to the followers of this theology. Rather than orientating itself along the lines of liberation theology with its option for the poor, it theologised wealth and simultaneously kept spiritual control over money by spiritualising richness and wealth (Heuser 2016:3). Gbotoe (2013:56) mentions the following factors that contributed to the proliferation of the prosperity gospel in Africa: poverty, consumerism, utilitarianism, and globalisation. He argues that traditional African religious beliefs created a fertile ground for the propagation of the core elements of the prosperity gospel.

It especially connected with the propensity towards ritual, ritual enactments of offerings, and elaborate rituals of gift exchange that characterises traditional African worship.

It must, however, be noted that the prosperity gospel, with the integration of material prosperity and the blessing of the Holy Spirit, also connects with, '...the long history of Christian mission and its concepts of social change' (Heuser 2015:22). Kwakye (2015:215-228) has shown that many mission societies regarded the Gospel as a tool for both communal and individual prosperity. If Kwakye's observations are correct, it might just be that the work of the many mission societies that focused on community transformation and communal improvement were actually preparing the way for the prosperity gospel.

The prosperity gospel seems to be paradoxical, perhaps due its transformative and adaptive nature. Although it made itself at home in many African countries and in countless African faith communities, Gifford (2015:97) found - in his careful analysis of the theology of David Oyedepo - that Oyedepo's particular Prosperity Theology is not '... African in the sense of having some special focus on Africa'. Oyedepo very seldom focuses on African or Nigerian realities, and does not attempt to address it; and Gifford is critical of Oyedepo's contribution of challenging Nigeria's socio-political system. On the other hand, Heuser (2015:19) refers to Ray McCauley from Rhema Bible Church in South Africa, and also mentions his involvement in the day-to-day politics of South Africa. He initially became involved in negotiations between political par- 
ties because, as he explained - 'I think we need to be a moral compass somewhere on the basis of what goes on in the country' (Mail \& Guardian 2015). In an opinion piece in the Star newspaper he took a strong stance on the issue of racism (The Star 2016). It is clear that McCauley, nearly an iconic example of 'prosperity theology' in South Africa, is willing to address socio-political issues, and that his theology represents an attempt to Africanise and localise prosperity theology (although more careful analyses will be needed to understand his position and role in terms of a discourse on decolonisation and coloniality.) Another example may be Prophet T.B. Joshua from Nigeria. His ministries certainly focusses on African realities as he distributes food parcels to the needy and issues bursaries to students (even though the ministries may be critiqued in many other facets).

In the South African context, the CRL Rights Commission started an investigation into Christian churches. In the Commission's (2016) preliminary report, the Commission says:

In recent years, scores of churches, religious Organisations, and traditional healing practices have mushroomed throughout the country, changing the face of the religious communities and practice irreversibly. Streets are marked with signs and advertisements with promises of miracles, ranging from healing to prosperity (CRL Rights Commission 2016:6).

This preliminary report explains the goals of the investigation as to (CRL Rights Commission 2016:3-4):

- Investigate and understand further issues surrounding the commercialisation of religion and traditional healing.

- Identify the causes underlying the commercialisation of religion and traditional healing.

- Understand the deep societal thinking that makes some members of our society vulnerable and gullible to views expressed and actions during religious ceremonies.

- Assess the religious framework and its relevance to deal with the prevailing religious challenges.

- Formulate findings and recommendations that address the status quo on commercialised religion and traditional healing.

- Investigate what the spread of religious institutions in the country is.

- Establish what various miraculous claims are made by religious leaders and traditional healers regarding the powers to heal and do miracles.

- Assess what form of legal framework regulates the religious and traditional sectors currently. 
It is difficult to describe all the facets of the prosperity gospel within the scope of this research. ${ }^{2}$ The Lausanne movement (2010) defined the prosperity gospel in the 2010 Cape Town Commitment as '. . the teaching that believers have a right to the blessings of health and wealth, and that they can obtain these blessings through positive confessions of faith and the "sowing of seeds" through financial or material gifts'. ${ }^{3}$ Heuser (2015:20) emphasises the focus of the prosperity gospel on a material sense of prosperity. He argues that the prosperity gospel is a rediscovery of the world at large, and a culture based on the material prosperity promises of the Gospel. Hunt (2000:332-333) states that the doctrine of the assurance of divine physical health and prosperity through faith is at the forefront of this expression of Christian faith. It means that 'health and wealth' are the automatic divine right of all Bible-believing Christians and may be procreated by faith as part of the package of salvation, since the atonement of Christ includes not just the removal of sin, but also the removal of sickness and poverty. There is a cause-and-effect relationship between God and the faithful. The understanding is that in a covenant relationship God will stay true to His promises and the covenant-followers will receive a multitude of blessings. This is why Gbotoe (2013:26) calls it a 'commercialized Gospel'. Gbotoe (2013:48) also draws attention to the Missiological motive argued by prosperity teachers - Christians must become wealthy because God wants everyone to prosper so that his word can spread throughout the world.

This phenomenon is wider than the Christian faith. Heuser (2015:23) also refers to Islam and African religions and says: 'Pentecostal Prosperity Gospel successfully traverses religio-scapes in which diverse traditions of Christianity, African religions, and Islam merge into the sacred economy of the material' (Heuser 2015:23). Köhrsen (2015:57) also underlines the economic side of this phenomenon and contends that the prosperity gospel influences the economic attitude of followers in a way that allows them to come to terms with modern capitalism. More and more theologians try to understand the prosperity gospel from the vantage point of the economy of the Spirit and how this impacts on behavioural changes, including attitudes towards material possessions, life and work, and how life in abundance materialises in this world (Biehl 2015:145). Perhaps the more popular description by Wikipedia (2017) summarises it best:

2 For a comprehensive description, see the recent volume edited by Andreas Heuser (2015), as well as his article in HTS (2016). Also Gbote and Kgatla in HTS (2014).

3 Michael Biehl (2015:140) voiced many of the concerns and critiques African theologians expressed about the initial statement by the Lausanne movement on Prosperity Gospel, especially because they did not look at its contextualisation in Africa (and Asia). 
Prosperity theology (sometimes referred to as the prosperity gospel, the health and wealth gospel, or the gospel of success) is a religious belief among some Christians, who hold that financial blessing and physical well-being are always the will of God for them, and that faith, positive speech, and donations to religious causes will increase one's material wealth.

And:

Prosperity theology views the Bible as a contract between God and humans: if humans have faith in God, he will deliver security and prosperity.

In the African context, and especially in African Pentecostalism, 'claiming domains of prosperity has become a generic theme...' (Heuser 2015:20). In terms of empirical findings, the PEW Research Centre (2010:32) has shown that African Christian adherents to the prosperity gospel understand it as a situation where God will grant wealth and good health to people who have enough faith. Heuser (2016:2) argues that ' ... an almost canonised notion of prosperity gospel has spilled over from Pentecostal milieus to other forms of African Christianity within the last two decades'.

\section{Engaging the Prosperity Gospel - the contextualisation of the Gospel}

The widespread occurrence and vitality of the prosperity gospel in Africa raises many questions in terms of engaging it from a Missiological point of view. The reflection on the Africanisation of Missiology represents an opportunity to approach this as an issue of contextualisation embedded in the discourse on the translatability of the Gospel (Sanneh 1989, Gbotoe 2013:122; see also Bevans and Schroeder 2004:386).

True Africanisation of Theology will always be a 'glocal' issue - i.e. both recognising the broader discourses in theology, but also the construction of a localised theology, a place to feel at home (see Walls in Bevans and Schroeder 2004:389). Bosch (1992:427) argued that mission as contextualisation involves the construction of a variety of 'local theologies'. The Africanisation of Theology must attend to ways in which the Gospel narrative relates to, and plays into, local narratives and theologies. The contextualisation of the Gospel demands engagement with the realities of local contexts, and a sensitivity towards marginalised people. Marginalised people are experts in contextualisation because they have a 'double-consciousness' that expose local realities that the centre is bound to miss (Tahaafe-Williams 2016:280-281). The central question is expressed by Bujo (1992:75) in his sharp formulation: 'In which way can Jesus Christ be an African among Africans according to their own religious experience?' This is echoed in one of the important recent ecumenical documents - Together towards life: 
The gospel takes root in different contexts through engagement with specific cultural, political, and religious realities. Respect for people and their cultural and symbolic life-worlds are necessary if the gospel is to take root in those different realities (Keum 2013:35).

The concept of the Africanisation of Theology carries within itself a number of anomalies. It tends to generalise the rich diversity of people and expressions of faith in Africa; it threatens to become a new form of colonialization of the mind; and it negates demographic and geographic particularities. True Africanisation will be a 'glocal' enterprise, creating places to feel at home while safeguarding the local commons, recently called the 'new' parish (Sparks et al 2014). Küster (2016:206) drew attention to the importance of local cultures strengthening themselves in hybrid forms as counter movements to the powerful forces of globalisation.

This research proposes that the best way to engage with the prosperity gospel will be to understand and encounter the phenomenon from a 'glocal' perspective. In this process, the rest of the research questions will now receive further attention.

\section{The relationship between the Prosperity Gospel and globalisation}

The prosperity gospel embraces globalisation and 'travels well' (Heuser 2016:1). Heuser (2016:3) argues that prosperity messages were made to travel internationally. It is extremely successful in terms of religious mobility, and a short overview of the genealogy of the prosperity gospel shows the strands of exported religion that was part-and parcel of many North American religious movements in the 20th century. It utilised new mass communication media such as radio and television, and, later on, social media, even to the extent that glamorous mass-media productions became a characteristic feature of preachers representing this kind of theology, especially in Africa. White and Assimeng (2016) have, for example, shown the impact and influence of televangelism in Ghanaian Pentecostal churches. This partially explains the ease with which it de-localised from its American origins and re-localised in the global South, and particularly in Africa.

Hunt (2000:334) even likened the prosperity gospel to the famous global franchise McDonalds, and notes that both the fundamentalist doctrines as well as the organisational structure of the various ministries tend to be very alike in form, direction and genre:

They are typically based on well-trained pastors, congregations, Bible schools which turn out hundreds of graduate ministers every year who extol the central tenets of the Faith gospel across the globe, and world-wide systems of communication with believers through publications and audio and visual tapes (Hunt 2000:334). 
Küster (2016) sketches a broader perspective. He argues that globalisation has stamped its mark on theology:

Especially those theologies which consider themselves as contextual undergo deep transformations from localization to deterritorialization, from being mono-cultural to hybridity and from being community centered to multiple belonging (Küster 2016:203).

He states that the emphasis is shifting from contextualisation to glocalisation - referring to the transformation from '... localization to deterritorialization, from being mono-cultural to hybridity and from being community centered to multiple belonging' (Küster 2016:203).

In summary - it is clear that the prosperity gospel thrives in a 'glocal' context, travels well and succeeds in utilising modern global media to serve its message. It made its way to, and conquered, the religious landscape in Africa (more specifically sub-Saharan Africa). It can be described as a global phenomenon, and as a movement it has benefited tremendously from globalisation. The prosperity gospel cannot be understood outside the broad framework of and characteristics of globalisation.

\section{The relationship between the Prosperity Gospel and local (economic) realities}

Heuser (2016:6) shows that one cannot come to a proper conclusion about the prosperity gospel from a global perspective alone - attention must be focussed on local realities as well. The whole phenomenon of the prosperity gospel is closely related to economic realities, and church members try to find a religious solution for their socio-economic problems (Gbotoe 2013:61,120). Many prosperityoriented churches are, for example, churches that can be described as centrifugal in orientation, attending to the practical social improvement of local communities, and playing an important role in shaping local economic realities. Many of the smaller prosperity oriented churches demonstrate a sensitivity towards marginalised people, articulating a 'silent theology of survival' (Heuser 2016:7). He draws attention to interesting quantitative empirical research done in South Africa that indicated the socially constructive, born-again consciousness of some prosperityoriented Pentecostal churches. These churches particularly show a high sensitivity towards poverty alleviation. Heuser (2016:7) acknowledges the influential role of Peter Berger in convincing him that Pentecostalism should be viewed as a positive resource for modern economic development, especially in the light of the transformational quality of Pentecostal Prosperity Theology. 
Wepener and Swart (2017) found that faith communities following the prosperity gospel generated religious social capital. According to them, there is enough sociological evidence available today to suggest that religious communities represent social spaces 'that may be particularly salient as repositories of social capital.' Their research concluded that these faith communities played an important role in poverty alleviation. Communities that succeeded in generating a high level of social religious capital achieved considerable success in serving the communities material needs, providing opportunities for personal development and community cooperation. There is, indeed, a facet of (and expressions of) prosperity churches that enables marginalised people to improve their lives and experience life in fullness (Tetzlaff 2015:38).

The differentiation in types of prosperity churches must also be kept in mind. Some of these churches are modelled on North American churches and represent a kind of McDonaldisation of the church. Others, perhaps such as those currently being investigated by the CRL Rights Commission, are churches that exist solely for the financial benefit of the church leadership - sometimes called 'prophets for profit'. Gbotoe (2013:70) also noted the glamorous lifestyle of prosperity preachers in Africa. There are, however, prosperity churches with a strong emphasis on the marginalised, and on bringing hope and life in fullness to local communities. We need to hear more of these stories...

Other observers differ, saying that the relationship between the prosperity gospel and local (economic) realities needs more research. Heuser (2016:8) concedes that '...the prosperity gospel and the connection between African Pentecostalism and socio-economic change defies a generalised view'. Research into the narratives of particular prosperity-oriented churches using, for example, the Missiological approach of Hendriks (2004), might reveal interesting facets of the relationship between the prosperity gospel and local (economic) realities. The so-called Pentecostalisation of mission theology found in the mission affirmation of the World Council of Churches (2013), Together towards Life (see Biehl 2015:141), with the focus on prosperity of life and affirming and preserving life for all of creation, also opens up interesting avenues of approach to develop this theme.

\section{The Prosperity Gospel as a form of colonialization}

The more complex question is whether the prosperity gospel can be regarded as a form of colonialization - a continuation of colonial influences on Africa, albeit in different guise? In much of the current discourse a distinction is made between 'colonialization' and 'coloniality'; implying a sensitivity towards the nuances in the discourses. 'Coloniality' refers to the persistent socio-economic and political stratification according to Eurocentric standards. 'Coloniality' is, in fact, the substance of 
the historical period of colonisation - its social constructions, imaginaries, practices, hierarchies, and violence. Decoloniality is a response to the relation of direct, political, social, and cultural domination established by Europeans and their EuroNorth American descendants (Quijano 2007:168). It represents a protest against the dominance of Eurocentric thinking.

The argument is far from obvious and clear. I experienced this first-hand when I discussed the investigation by the CRL Rights Commission with a class of senior students, mostly from Africa. I assumed that senior students in theology, trained at a predominantly reformed faculty of theology, would naturally be very sceptical towards the prosperity gospel, would applaud the government investigation into religious malpractices, and would take a strong position against any theology developing a cause-and-effect relationship between God and the faithful. I was quite surprised to observe deep sympathy - if not outright support - for the prosperity gospel. This encouraged me to, at least, open up the debate about the relationship between the prosperity gospel and decolonialising theology.

The discussion on the genealogy of the prosperity gospel has shown how it is deeply indebted to, and influenced by, globalisation, and how it gained influence precisely because of its ability to 'travel well' and embrace the opportunities availed by globalisation. Grosfoguel (2011) indicated the close relationship between colonialization and globalisation. Ideas developed by Grosfoguel and others have shown the epistemological connection between coloniality and globalisation, especially the success of the modern/colonial world-system in dominating the world (and the idea that the Eurocentric [Western European] way of thinking are universally applicable, see Quijano 2000: 544,549).

The first question in terms of the investigation into the prosperity gospel as a form of coloniality is whether it challenges the epistemic system or, more precisely, the epistemic hierarchy that privileges Western knowledge and cosmology over non-Western knowledge and cosmologies? Can the prosperity gospel be understood as a form of global contextualisation of the Gospel of Jesus Christ that challenges global power systems, or the empire? My initial response will be to state that the prosperity gospel represents a form of global capitalism that has succeeded in spiritualising the materiality of that system. Hunt (2000:332) has placed the 'cultural origins' of the prosperity gospel, with its materialist orientation, firmly within the North American 'supply-side spirituality'. The underlying epistemology is more oriented towards buttressing the worldview of global capitalism than deconstructing the political, social, and cultural domination established by Europeans and their Euro-North American descendants. It represents a new kind of spiritual domination, and much of the symbols used in prosperity gospel rituals, and in the public demeanour of leaders, are closely modelled on the symbolic universe of the origi- 
nal leadership of the initial 'Faith Movement'. Heuser (2016:3) mentions the fact that many of the African recipients of American 'prosperity theology' received their theological education in North American Faith Gospel milieus, and that they evolved as prosperity megastars of their own, closely modelled on their mentors. These early adapters again mentored a new generation of African prosperity theologians.

The second question relates to the economic impact of the prosperity gospel. Grosfoguel (2011) defined coloniality as a particular global class formation where a diversity of forms of labour (slavery, semi-serfdom, wage labour, petty-commodity production etc.) are going to coexist and be organised by capital as a source of production of surplus value through the selling of commodities for a profit in the world market. The core of the prosperity gospel is a spiritualisation of materiality and raising classic symbols of surplus excess (such as expensive motorcars, private jets, and other symbols of affluence) as symbols of holiness and God's blessing. Gbotoe (2013:70) describes the lifestyle of prosperity gospel preachers as corrupt and lavish. The prosperity gospel thrives on the consumerist ideology. The benefits of this theological approach are not for the corporate church, but are blessings showered on the individual believer. Hunt argues that this brings prosperity doctrines in line with a culture which places the individual as the subject of consumerism. Rather than challenging the 'colonial power matrix', the prosperity gospel sanctifies it. Hunt (2000:334) does not mince his words when stating that the genealogical parent of the prosperity gospel, the 'Faith movement', should be interpreted as the justification of the Western economic free market. Heuser (2016:5) also refers to research into Nigerian megachurches that are not much more than business empires led by business-minded religious entrepreneurs called 'prophets for profit'. They use business and marketing strategies to generate income and '.. act as "economic missionaries" with a prime interest in generating rent instead of supporting spiritual aims'.

The issue of contextualisation also involves the construction of a variety of local theologies, and attention must be given to local narratives and theologies. Comaroff (2015:227) and Coleman (2011:33) drew attention to a different reading of Pentecostalism as a kind a religiosity integrated with ordinary life, and as a way in which people can address economic marginalisation. Fröchling (2015:328) has shown that there is a change in the grass-roots level understanding of the prosperity gospel amongst some Nigerian migrants in South Africa towards a more justice-orientation that includes the well-being of the community. Although Heuser (2016:8) reminds us that the Pentecostal narrative of social awareness, in most cases, follows the prosperity gospel semantics of success, transformation, and visibility in society, he also recognises changes and an increased focus on socio-economic change and nurturing an entrepreneurial ethos. I previously referred to the existence of pros- 
perity churches with a strong focus on local communities and marginalised people - churches that succeeded in changing the outlook of members towards economic challenges, and assisted in empowering its membership to take responsibility for their own lives and future. Wepener and Swart (2017) showed that aspects of prosperity gospel became, in practise, a kind of bonding social capital that represents a critically important part of the fight against poverty. ${ }^{4}$

In conclusion - one must heed the warning by Heuser (2016:7) and Drønen (2015:263) that the debate on the connection between Pentecostal techniques of personal transformation and empowerment for social changes is still open and growing.

The third question relates to the broader approach to liberation and transformation. Grosfoguel (2011) argues for the '...broader transformation of the sexual, gender, spiritual, epistemic, economic, political, linguistic, aesthetic, pedagogical and racial hierarchies of the "modern/colonial western-centric Christian-centric capitalist/patriarchal world-system"'. It is beyond the scope of this paper to address all the wide-ranging issues today, but if one looks at the sexual and gender debate in Africa, especially in terms of same-sex relations, it seems as if the myriad of churches that can broadly be categorised as part of the prosperity gospel, continue the fundamentalist approaches of North American Pentecostalism. But the prosperity gospel also plays into this issue in a paradoxical way - Gbote and Kgatla (2014:5) argue that the ineffectiveness of the state to provide basic services in certain African contexts makes '...the prosperity theology seem as true liberation'. Church members in the prosperity gospel movement look up to their spiritual leaders as liberators and hope-givers.

\section{Conclusion}

The prosperity gospel represents one of the most interesting challenges to missiologists. The discourses on the Africanisation of theology and, more specifically, Missiology, will have to attend to the paradoxical influence of the prosperity gospel. On the one hand, it represents much of the global Eurocentric (and especially North American) influences attacked by the decolonial discourse. This researched showed how the prosperity gospel abducted the missionary imagination of many churches in Africa and replaced it with a materialistic and consumerist orientation. On the other hand, local expressions of prosperity churches, and the way in which these churches embrace marginalised peoples and are contextually sensitive, might

\footnotetext{
4 Wepener and Swart (2017):'Communities that succeed in generating a high level of social capital, are, in many cases, communities successful in co-operation. They are able to provide in material needs and to open better opportunities for people.'
} 
just lead to a particular form of African Pentecostalism that will, by itself, deconstruct the coloniality debate and add exciting dimensions to the debate.

\section{Bibliography}

Bevans, Stephen \& Schroeder, Roger, 2004, Constants in context: A Theology of mission for today, Orbis, Maryknoll.

Biehl, Michael, 2015, "To prosper and be blessed: prosperity, wealth and "life in abundance" in ecumenical debate' in Andreas Heuser (ed.), Pastures of plenty: Tracing religioscapes of the prosperity gospel in Africa and beyond, pp. 131-145, Peter Lang, Frankfurt.

Bosch, David, 1992, Transforming Mission, Orbis, Maryknoll.

Bujo, Bénézet, 1992, African theology in its social context, Orbis, Maryknoll.

Coleman, S., 2011, 'Prosperity unbound? Debating the "Sacrificial Economy", in L. Obadia \& D. Wood (eds.), The economics of religion: Anthropological approaches, pp. 23-45, Bingley, Emerald.

Comaroff, Jean, 2015, 'Pentecostalism, "Post-Secularism", and the politics of affect in Africa and beyond', in M. Lindhardt (ed.), Pentecostalism in Africa: Presence and impact of Pneumatic Christianity in postcolonial societies, pp. 220-247, Brill, Leiden.

Commission for the Promotion and Protection of the Rights of Cultural, Religious and Linguistic Communities (CRL Rights Commission), 2015, accessed from http://www.crlcommission.org.za/ on 10 Jan. 2017.

Commission for the Promotion and Protection of the Rights of Cultural, Religious and Linguistic Communities (CRL Rights Commission), 2016, CRL Rights Commission's preliminary report of the hearings on commercialisation of religion and abuse of people's belief systems, CRL Rights Commission, Johannesburg.

Drønen, Tomas S., 2015, “Now I dress well. Now I work hard” - Pentecostalism, prosperity, and economic development in Cameroon', in A. Heuser (ed.), Pastures of plenty: Tracing religio-scapes of the prosperity gospel in Africa and beyond, pp. 249-263, Lang, Frankfurt.

Fröchling, Drea, 2015, 'Between gutter and Gucci, Boss and Botho: a relocation of the "Prosperity Gospel" by Nigerian Pentecostal Christians in Soweto, South Africa' in Andreas Heuser (ed.), Pastures of plenty: Tracing religio-scapes of the prosperity gospel in Africa and beyond, pp. 326-338, Peter Lang, Frankfurt.

Gbotoe, Eric Z.M., 2013. 'Commercialized Gospel: a missiological assessment of Prosperity Gospel', M.A. (Theology) Dissertation, University of Pretoria, Pretoria. Accessed from http://www.repository.up.ac.za/handle/2263/40347 on 9 February 2017.

Gbote', Eric Z.M. \& Kgatla, S. Thias, 2014, 'Prosperity gospel: A missiological assessment', HTS Teologiese Studies/ Theological Studies 70(1), Art. \#2105, DOI: 10.4102/hts. v70i1.2105.

5 The author is incorrectly indicated as Gbote, but research into original sources showed his surname to be Gbotoe. 
Grossfoguel, Ramon, 2011, 'Decolonizing post-colonial studies and paradigms of political economy: Transmodernity, decolonial thinking, and global coloniality', Transmodernity: Journal of Peripheral Cultural Production of the Luso-Hispanic World 1(1): 37.

Hendriks, H. Jurgens, 2004, Studying congregations in Africa, Lux Verbi BM, Wellington. Heuser, Andreas, 2016, 'Charting African prosperity gospel economies', HTS Teologiese Studies/Theological Studies 72(1), Art. \#3823, DOI: 10.4102/hts.v72i1.3823.

Heuser, Andreas, 2015, 'Religio-scapes of the prosperity gospel: An introduction' in Andreas Heuser (ed.), Pastures of plenty: tracing religio-scapes of the prosperity gospel in Africa and beyond, pp. 15-30, Peter Lang, Frankfurt.

Hunt, Stephen, 2000, "Winning ways": Globalisation and the impact of the health and wealth gospel', Journal of Contemporary Religion 15(3): 331-347.

Keum, Jooseop (ed.), 2013, Together towards life: Mission and evangelism in changing landscapes, with a practical guide, WCC Publications, Geneva.

Köhrsen, Jens, 2015, 'Pentecostal improvement strategies: a comparative reading on African and South American Pentecostalism', in Andreas Heuser (ed.), Pastures of plenty: tracing religio-scapes of the prosperity gospel in Africa and beyond, pp. 49-64, Peter Lang, Frankfurt.

Küster, Volker, 2016. 'From Contextualization to Glocalization. Intercultural Theology and Postcolonial Critique', Exchange 45:203-226.

Kwakye, Abraham Nana Opare, 2015, 'Encountering "prosperity” gospel in nineteenth century Gold Coast: Indigenous perceptions of Western missionary societies', in Andreas Heuser (ed.), Pastures of plenty: tracing religio-scapes of the prosperity gospel in Africa and beyond, pp. 217-228, Peter Lang, Frankfurt.

Lausanne III., 2011, 'Cape Town Commitment', Lausanne III - International Congress on World Evangelization, Cape Town, 16-25 October 2010.

Mail \& Guardian, 2015, Who gets to bold a society's moral authority? Accessed from http://mg.co.za/article/2015-02-19-who-gets-to-hold-a-societys-moral-authority on 11 Jan. 2017.

Pew Research Centre, 2010, Tolerance and tension: Islam and Christianity in Sub-Sabaran Africa, Pew Forum on Religion \& Public Life, accessed from http://www.pewforum. org/2010/04/15/executive-summary-islam-and-christianity-in-sub-saharan-africa/ on 10 Jan. 2017.

Quijano, Aníbal, 2007, 'Coloniality and modernity/rationality', Cultural Studies 21(2\&3): 168-178.

Quijano, Aníbal, 2000, 'Coloniality of power, Eurocentrism, and Latin America', Nepantla: Views from South 1(3): 533-580.

Sanneh, Lamin, 1989, Translating the message: The missionary impact on culture, Orbis, Maryknoll.

Star, 2016, 'Not possible to be religious and racist', 26 April 2016, accessed from http:// www.iol.co.za/the-star/not-possible-to-be-religious-and-racist-2014589 on 11th Jan. 2017.

Tahaafe-Williams, Katalina, 2016, 'Contextualisation' in Kenneth Ross, Jooseop Keum, Kyriaki Avtzi and Rodercik Hewitt (eds.), Ecumenical Missiology. Changing landscapes 
and new conceptions of mission, pp.271-281, Regnum (Regnum Edinburgh Centenary Series 35), Oxford.

Tetzlaff, Rainer, 2015, 'Political architecture of poverty: on changing patterns of "African identity", in Andreas Heuser (ed.), Pastures of plenty: tracing religio-scapes of the prosperity gospel in Africa and beyond, pp. 33-48, Peter Lang, Frankfurt.

White, Peter \& Assimeng, A.A., 2016, 'Televangelism: A study of the "Pentecost hour" of the Church of Pentecost', HTS Teologiese Studies/ Theological Studies 72(3), Art. \#3337, DOI: $10.4102 /$ hts.v72i3.3337.

Wepener, Cas \& Swart, Ignatius, "Wyn, brood en KFC vir Afrika se honger," Beeld, April 8, 2017, http://www.netwerk24.com/Stemme/Menings/wyn-brood-en-kfc-vir-afrika-sehonger-20170407 (accessed on June 7, 2017).

Wikipedia, Prosperity theology, accessed from https://en.wikipedia.org/wiki/Prosperity_ theology on 10 Jan. 2017.

World Communion of Reformed Churches, 2004, Accra-confession, accessed from http:// wcrc.ch/accra on 3 March 2017. 